\title{
Potassium and growth-promoting fungi improve the postharvest quality of grape tomato
}

\section{Potássio e fungos promotores de crescimento melhoram a qualidade pós-colheita de minitomates}

\author{
Deise Silva Castro Pimentel Cardoso ${ }^{1 *}$; Herminia Emilia Prieto Martinez2; Ariana \\ Mota Pereira'; Maria Catarina Megumi Kasuya3; Paulo Roberto Cecon ${ }^{4}$
}

\section{Highlights}

Adequate $\mathrm{K}$ concentration ensures better postharvest quality of grape tomato fruits.

Growth-promoting fungi improve the nutritional balance of grape tomato plants.

At low and high $\mathrm{K}$ rates, GPF improve the postharvest quality of grape tomato

\begin{abstract}
Tomato plants respond well to potassium fertilization, whose insufficiency leads to a drop in fruit production and quality. On the other hand, the association of growth-promoting fungi (GPF) with roots has been shown to be able to optimize nutrient absorption, which implies lower financial costs and a decreased risk of loss of $\mathrm{K}$ applied to the soil. The objective of this study was to investigate the effects of inoculation with GPF and $\mathrm{K}$ rates on the postharvest quality of grape tomato hybrid 'Mascot' grown in a hydroponic system. The plants were cultivated in a hydroponic drip system using washed and sterilized sand as substrate. They were trained with two stems, leaving three bunches per stem. The experiment was carried out in a splitsplit-plot arrangement in a completely randomized design with three replicates. Ripe fruits were stored for 30 days in PET containers in storage chambers at a temperature of $25^{\circ} \mathrm{C}$. After $0,10,20$ and 30 days of storage, five fruits were collected to determine the titratable acidity (TA) and soluble solids (SS), reducing sugars (RS) and vitamin $\mathrm{C}$ contents. The $\mathrm{K}$ rates provided an increase in the quality attributes. At low $\mathrm{K}$ rates, inoculation with GPF led to higher TA, SS, RS and vitamin C values. Inoculation of the plants with GPF improved the postharvest preservation of the fruits, especially when the plants underwent nutritional stress during cultivation.
\end{abstract}

Key words: Nutrient solution. Solanum lycopersicum L.. Storage. Symbiosis.

1 Agricultural Engineer, PhD in Plant Science, Universidade Federal de Viçosa, UFV, Viçosa, MG, Brazil. E-mail: deise1pimentel@yahoo.com.br; ariana.mota@ufv.br

2 PhD Professor, Department of Agronomy, Graduate Program in Plant Science, UFV, Viçosa, MG, Brazil. E-mail: herminia@ufv.br

3 PhD Professor, Department of Microbiology, Graduate Program in Agricultural Microbiology, UFV, Viçosa, MG, Brazil. E-mail: mkasuya@ufv.br

${ }^{4}$ PhD Professor, Department of Statistics, Graduate Program in Applied Statistics and Biometrics. UFV, Viçosa, MG, Brazil. E-mail: cecon@ufv.br

* Author for correspondence

Received: Sept. 11, 2020 - Approved: Dec. 03, 2021 


\section{Resumo}

O tomateiro responde bem à fertilização potássica, cuja insuficiência acarreta queda na produção e qualidade dos frutos. Por outro lado, a associação de fungos promotores de crescimento (FPC) com raízes tem-se mostrado capaz de otimizar a absorção de nutrientes, o que implica menor custo financeiro e menor risco de perdas do $\mathrm{K}$ aplicado ao solo. $\mathrm{O}$ objetivo deste trabalho foi estudar os efeitos da inoculação com FPC e de doses de K na qualidade pós-colheita do minitomate hibrido Mascot cultivado em hidroponia. As plantas foram cultivadas em sistema hidropônico de gotejamento, usando areia lavada e esterilizada como substrato. Foram conduzidas com duas hastes, deixando-se três cachos por haste. $\mathrm{O}$ experimento foi realizado em parcelas sub-subdividadas e em delineado inteiramente ao acaso, com três repetições. Os frutos maduros foram armazenados por 30 dias em embalagens PET em câmaras de armazenamento à temperatura de $25^{\circ} \mathrm{C}$. Após 0, 10, 20 e 30 dias de armazenamento coletaram-se 5 frutos para determinação do teor de sólidos solúveis (SS), acidez titulável (AT), de açúcares redutores (AR) e vitamina C. As doses de $\mathrm{K}$ tiveram efeito crescente nos atributos de qualidade. Em baixas doses de $\mathrm{K}$ a inoculação com FPC resultou em maiores valores de SS, AT, AR e vitamina C. A inoculação das plantas com FPC promoveu melhor conservação dos frutos na pos-colheita, especialmente quando as plantas sofreram estresse nutricional durante o cultivo.

Palavras-chave: Armazenamento. Simbiose. Solanum lycopersicum L.. Solução nutritiva.

\section{Introduction}

Hydroponic cultivation of grape tomato has been growing and spreading worldwide, thanks mainly to gains in yield and product quality. The drip system in bags or pots filled with substrates is the most used in the production of this fruit (Alvarenga, 2013). However, the inadequate management of this technique, characterized by high rates of commonly used nutrients, has been one of the main causes of substrate salinization, which has contributed to decreased yields (Eloi, Duarte, \& Soares, 2007). Furthermore, the excessive use of chemical fertilizers can cause toxicity to plants, wastage of nutrients and salinization of the environment by the drained nutrient solution (Kawakami, Araujo, lunck, Factor, \& Cortez, 2007).

Potassium is one of the macronutrients most required by tomato plants. The element is essential for being one of the main enzyme activators; acting in the translocation of photoassimilates; regulating cell osmotic pressure; and controlling stomatal opening and closure. In addition to being important processes for the regulation of the plant's transpiration, stomatal opening and closure greatly affect the photosynthetic rate, since, in K-deficient plants, stomatal opening does not occur regularly, reducing the $\mathrm{CO}_{2}$ input (Marschner, 2012; Taiz, Zeiger, \& Moller, 2017).

The influence of $K$ in the abovedescribed biochemical processes results in relevant effects on the postharvest quality of fruits, affecting attributes such as color, size, acidity, resistance to transport, handling and storage, nutritional value and industrial aspects (Asaduzzaman \& Asao, 2018).

Recent studies have shown that adjusting fertilization and inoculation with growth-promoting fungi can contribute 
to a more sustainable management of agricultural production. These fungi are able to increase plants' nutrient uptake through the extracellular network of hyphae; tolerance to droughts and salt stress; resistance to the effects of heavy metals (Varma, Bakshi, Lou, Hartmann, \& Oelmueller, 2012); and photosynthetic efficiency (Achatz et al., 2010; Boldt et al., 2011; Yadav, Aggarwal, \& Singh, 2013).

Tomato plants are highly mycorrhizal, and besides improving their performance, the effects of said association can also favor fruit quality. Giovannetti et al. (2012) observed higher concentrations of $\mathrm{P}, \mathrm{Zn}$ and lycopene in the fruits of tomato plants inoculated with Glomus intraradices. Wang et al. (2015) found that tomato plants colonized by Piriformospora indica showed a higher ratio of soluble solids content to titratable acidity as well as increased firmness. Hart et al. (2014) observed that tomato plants inoculated with arbuscular mycorrhizal fungi (AMF) produced fruits with better quality, with a higher concentration of minerals, antioxidants, carotenoids, vitamins and flavoring compounds (sugars, titratable acidity and volatile compounds).

Emmanuel and Babalola (2020) argued that in addition to modifying the architecture of roots and increasing the uptake of $\mathrm{P}, \mathrm{K}$ and micronutrients, mycorrhizal fungi induce changes in the primary and secondary metabolism of plants, which are responsible for the multiple benefits of this symbiosis to plants.

Tomato is a highly perishable fruit due to the fragility of its tissues and the maintenance of metabolic activity after harvesting. For this reason, its preservation requires countless efforts (Ferraz et al., 2012), such as controlling the temperature and relative humidity and using adequate packaging during the storage period. In the available literature, no studies were found that evaluated the effect of mycorrhization of tomato on the postharvest preservation of this crop.

This study was developed to examine the influence of the $\mathrm{K}$ rate and inoculation with AMF and $P$. indica on the postharvest quality of fruits of the grape tomato hybrid 'Mascot' grown in a hydroponic drip system.

\section{Material and Methods}

The experiment was carried out in a greenhouse at the Department of Plant Science at the Federal University of Viçosa, Minas Gerais, Brazil (2045'14" S, 4252'55" W, $648 \mathrm{~m}$ above sea level), from June to October 2017. The greenhouse has a 2.4-m ceiling height and was covered with transparent glass, protected with anti-aphid mesh on the sides and non-air-conditioned.

Grape tomato plants were grown in a hydroponic system, inside $8-L$ plastic pots containing washed and sterilized sand. The nutrient solution was supplied by a drip system with one emitter per plant. The solution was pumped from 180-L reservoirs through a 0.25 horsepower (CV) motor-pump set that fed the irrigation lines. Pump activation occurred daily, by a timer, at 00h00, 06h00, 09h00, $11 \mathrm{~h} 00,12 \mathrm{~h} 00,14 \mathrm{~h} 00,15 \mathrm{hO0}$ and $18 \mathrm{~h} 00$. The flow rate was 100 and $200 \mathrm{~mL}$ per minute for the vegetative (0-30 days after transplanting [DAT]) and reproductive (30 to 120 DAT) phases, respectively, and was determined by previous tests so that drainage and disposal did not exceed $10 \%$ of the applied volume. 
The nutrient solutions used were based on those described by Fernandes, Martinez and Fontes (2002), but at $40 \%$ of the ionic strength. For the vegetative growth phase, the following contents were used: 3.2, $0.8,1.6,0.8,0.4$ and $0.4 \mathrm{mmol} \mathrm{L}^{-1}$ of N, P, K, Ca, $\mathrm{Mg}, \mathrm{S}$; and 14, 7.6, 8.4, 1.6, 0.36 and $0.28 \mu \mathrm{mol}$ $\mathrm{L}^{-1}$ of $\mathrm{Fe}, \mathrm{Mn}, \mathrm{B}, \mathrm{Zn}, \mathrm{Cu}, \mathrm{Mo}$, respectively. After flowering, a fruiting nutrient solution with the following composition was used: $4.8,1.2,1.2$, 0.6 and $0.6 \mathrm{mmol} \mathrm{L}^{-1}$ of $\mathrm{N}, \mathrm{P}, \mathrm{Ca}, \mathrm{Mg}, \mathrm{S}$; and 23.6, 8, 10, 1.6, 0.52 and $0.28 \mu \mathrm{mol} \mathrm{L}^{-1}$ of Fe, $\mathrm{Mn}, \mathrm{B}, \mathrm{Zn}, \mathrm{Cu}$ and Mo, respectively. The $\mathrm{K}$ rates were $0.8,2,3$ or $4 \mathrm{mmol} \mathrm{L}^{-1}$.

Grape tomato hybrid 'Mascot' was used due to its high 'Brix value, high yield and low lateral budding. The seeds were provided by the Agristar company and inoculated with a mixture of arbuscular mycorrhizal fungi (AMF) (Rhizophagus clarus, Claroideoglomus etunicatum and Gigaspora albida), with structures of the fungus Piriformospora indica. In control treatment, the seeds remained uninoculated. The choice of the fungi was based on preliminary tests carried out in the microbiology section at UFV. Plants were subjected to four rates of $\mathrm{K}(0.8,2,3$ and $4 \mathrm{mmol} \mathrm{L}^{-1}$ ) in the reproductive phase. A splitsplit-plot arrangement was used in which the $K$ rates represented the plots, the inoculated and uninoculated plants the subplots and the fruit storage periods $(0,10,20$ and 30 days of storage [DOS]) the sub-subplots. The experiment was laid out in a completely randomized design with three replicates.

Seedlings were produced in 128cell Styrofoam propagation trays containing substrate based on coconut fiber. Inoculation with the AMF mixture was carried out by adding a 20-mL pipe of autoclaved sand containing, on average, 16 fungal spores per $\mathrm{g}$ of sand.
Inoculation with $P$. indica was achieved by adding a disk of culture medium containing fungal structures $5 \mathrm{~mm}$ in diameter to each cell of the tray. After inoculation, two seeds were sown per cell, which were irrigated with water until germination. After germination, the seedlings were irrigated with a nutrient solution by Fernandes et al. (2002), diluted to $50 \%$. Upon showing two definitive leaves, the seedlings were transplanted to 8-L plastic pots containing washed and sterilized sand.

The plants were trained at a spacing of $0.5 \mathrm{~m}$ between plants and $1.0 \mathrm{~m}$ between rows, with two stems, which were staked by plastic strings tied perpendicularly to the bench. Apical pruning was performed in a position superior to the third leaf above the third floral cluster of each stem. Shoot thinning was frequently performed to eliminate lateral shoots.

During cultivation, powdery mildew (Oidium sp) was curatively treated with two sprays of raw cow's milk at $10 \%(\mathrm{v} / \mathrm{v})$ on the leaves (Bettiol, Astiarraga, \& Luiz, 1999). Tomato borer (Tuta absoluta) and whitefly (Bemisia tabaci) were also curatively treated with three applications of Abamectin ${ }^{\circledR}$ : one in the vegetative stage and two in the reproductive stage (Abamectin $15 \mathrm{~mL}$ to $20 \mathrm{~L}$ ).

Ripe fruits were harvested weekly from 90 DAT. Samples of $400 \mathrm{~g}$ of ripe commercial fruits from the third and fourth floral bunches were packed in PET containers and stored for 30 days (30 DOS) in chambers with controlled temperature at $25^{\circ} \mathrm{C}$. Evaluations were performed at 0, 10, 20 and 30 DOS.

At each evaluation period, five fruits were collected to analyze titratable acidity (TA) and the soluble solids (SS), reducing sugars (RS) and vitamin C (vit. C) contents. 
Soluble solids were determined by direct reading in a digital refractometer using the undiluted fruit pulp, with values expressed in ${ }^{\circ}$ Brix.

Titratable acidity was expressed in grams of citric acid per $100 \mathrm{~g}$ of pulp and measured by the titration of $5 \mathrm{~g}$ of homogenized pulp diluted in $100 \mathrm{~mL}$ of distilled water with a standardized $0.1 \mathrm{M}$ sodium hydroxide solution until the sample reached $\mathrm{pH}$ 8.1.

Reducing sugars were determined based on the method described by McCready, Guggolz, Silveira and Owens (1950). The dinitrosalicylic acid method was employed for quantification (Gonçalves, RodriguesJasso, Gomes, Teixeira, \& Belo, 2010), with $0.2 \%$ fructose used as standard solution and reading in a molecular absorption spectrophotometer at $540 \mathrm{~nm}$. Results were expressed as a percentage of fresh weight.

The vit. $\mathrm{C}$ content was determined by titration, in a modified version of the method of Strohecker and Henning (1967). Results were expressed in milligrams of ascorbic acid per $100 \mathrm{~mL}$ of sample.

Data were subjected to analysis of variance and regression using the System for Statistical and Genetic Analysis (SAEG). For the qualitative factor, means were compared by Tukey's test, adopting the $5 \%$ probability level. For the quantitative factor, regression analysis was used and the models were chosen based on the significance of the regression coefficients, the coefficient of determination (R2, SS Regression/SS Treatment) and biological behavior. Regardless of whether or not the interaction of highest degree was significant, it was not decomposed.

\section{Results and Discussion}

All evaluated traits varied significantly with increasing $\mathrm{K}$ rates in the nutrient solution and with storage time. All traits were significantly affected by the interaction between $\mathrm{K}$ rate, storage time and presence of growth-promoting fungi (GPF), which shows that the effect of root colonization with GPF on the quality of tomato fruits depends on the rate of potassium used in cultivation and on storage time.

At 10 DOS, the SS content ('Brix) of the fruits of plants grown at the lowest $K$ rate ( $\left.0.8 \mathrm{mmol} \mathrm{L}^{-1}\right)$ was higher in the presence of GPF, mainly with $P$ indica. At 20 DOS, however, there was a positive effect of the association with AMF at the $\mathrm{K}$ rate of $3.0 \mathrm{mmol} \mathrm{L}^{-1}$ (Table 1). Because there was no difference in the ${ }^{\circ}$ Brix of the fruits obtained from inoculated and uninoculated plants at 0 DOS, these higher SS values at 10 and 20 DOS may be related to the drying of the fruits, which resulted in fresh weight loss, thus concentrating the sugars in the interior of the tissues during these storage periods. In addition, these values may also be related to ripening reactions that increase the conversion of organic acids or the breakdown of starch into glycolytic pathway intermediates, such as phosphate trioses, to phosphate hexoses (Cakmak, 2005; Chitarra \& Chitarra 2005) in presence of GPF. 
Table 1

Soluble solids ( $\left.{ }^{\circ} \mathrm{Brix}\right)$ of grape tomatoes grown under $\mathrm{K}$ rates and inoculated with growth-promoting fungi, at $0,10,20$ and 30 days of storage at $25^{\circ} \mathrm{C}$

\begin{tabular}{|c|c|c|c|c|c|c|c|c|}
\hline \multicolumn{9}{|c|}{ Storage time } \\
\hline \multirow{3}{*}{ Inoculum } & \multicolumn{4}{|c|}{0 days } & \multicolumn{4}{|c|}{10 days } \\
\hline & \multicolumn{4}{|c|}{ Rate $\left(\mathrm{mmol} \mathrm{L}^{-1}\right)$} & \multicolumn{4}{|c|}{ Rate $\left(\mathrm{mmol} \mathrm{L}^{-1}\right)$} \\
\hline & 0.8 & 2 & 3 & 4 & 0.8 & 2 & 3 & 4 \\
\hline Control & $6.8 \mathrm{a}$ & $7.54 \mathrm{a}$ & $7.6 \mathrm{a}$ & $8.91 \mathrm{a}$ & $6.11 b$ & $7.31 \mathrm{a}$ & $7.06 \mathrm{a}$ & $8.0 \mathrm{a}$ \\
\hline P. indica & $7.15 \mathrm{a}$ & $7.48 \mathrm{a}$ & $7.82 \mathrm{a}$ & $8.52 \mathrm{a}$ & $6.95 \mathrm{a}$ & $7.06 \mathrm{a}$ & $7.18 \mathrm{a}$ & $7.38 \mathrm{a}$ \\
\hline AMF & $7.22 \mathrm{a}$ & $7.48 \mathrm{a}$ & 7.97 a & $8.11 \mathrm{a}$ & $6.61 \mathrm{ab}$ & $6.98 \mathrm{a}$ & $7.41 \mathrm{a}$ & $7.63 \mathrm{a}$ \\
\hline \multicolumn{9}{|c|}{ Storage time } \\
\hline \multirow{3}{*}{ Inoculum } & \multicolumn{4}{|c|}{20 days } & \multicolumn{4}{|c|}{30 days } \\
\hline & \multicolumn{4}{|c|}{ Rate $\left(\mathrm{mmol} \mathrm{L}^{-1}\right)$} & \multicolumn{4}{|c|}{ Rate $\left(\mathrm{mmol} \mathrm{L}^{-1}\right)$} \\
\hline & 0.8 & 2 & 3 & 4 & 0.8 & 2 & 3 & 4 \\
\hline Control & $5.08 \mathrm{a}$ & $5.78 \mathrm{a}$ & $5.6 \mathrm{~b}$ & $6.65 \mathrm{a}$ & $5.75 \mathrm{a}$ & $5.43 \mathrm{a}$ & $5.9 a$ & $6.93 \mathrm{a}$ \\
\hline P. indica & $5.70 \mathrm{a}$ & $5.8 \mathrm{a}$ & $5.98 a b$ & $6.35 \mathrm{a}$ & $5.71 \mathrm{a}$ & $5.90 \mathrm{a}$ & $6.51 \mathrm{a}$ & $6.85 a$ \\
\hline AMF & $5.80 \mathrm{a}$ & $6.05 \mathrm{a}$ & $6.23 \mathrm{a}$ & $6.43 \mathrm{a}$ & $5.86 \mathrm{a}$ & $6.01 \mathrm{a}$ & $6.61 \mathrm{a}$ & $6.60 \mathrm{a}$ \\
\hline CV (a) & \multicolumn{8}{|c|}{11.94} \\
\hline$C V(b)$ & \multicolumn{8}{|c|}{11.12} \\
\hline CV (c) & \multicolumn{8}{|c|}{6.38} \\
\hline
\end{tabular}

Means followed by the same lowercase letter in the column do not differ from each other by Tukey's test at $5 \%$ probability. CV (a): coefficient of variation of the plot, CV (b): coefficient of variation of the subplot, CV (c): coefficient of variation of the sub-subplot.

The evaluations performed at the different storage periods in fruits of both inoculated and uninoculated plants revealed increases in SS with increasing $\mathrm{K}$ rates, except for the fruits obtained from inoculation with $P$. indica and AMF at 10 and 20 DOS (mean values: 7.14 and 6.12 for $P$. indica and AMF, respectively) (Figure 1). In these cases, the presence of fungi stabilized the SS concentration regardless of the $\mathrm{K}$ rate. The SS values measured in ${ }^{\circ} \mathrm{Brix}$ ranged from 7.71 to 6.0; 7.74 to 6.24 ; and 7.69 to 6.27 throughout storage at $25^{\circ} \mathrm{C}$ for control, P. indica and AMF, respectively (Figure 1).
The increase in SS in the fruits with the increasing $K$ rates at harvest (O DOS) and during storage (Figure 1 ) is due to the important role that this nutrient plays in the translocation of photoassimilates and in the activation of several enzymes. The positive influence of increasing the $\mathrm{K}$ rate on SS has been shown in several studies with tomato (Liu, Zhang, Tan, \& Astatkie, 2011; Sonntag, Naumann, Pawelzik, \& Smit, 2019). 

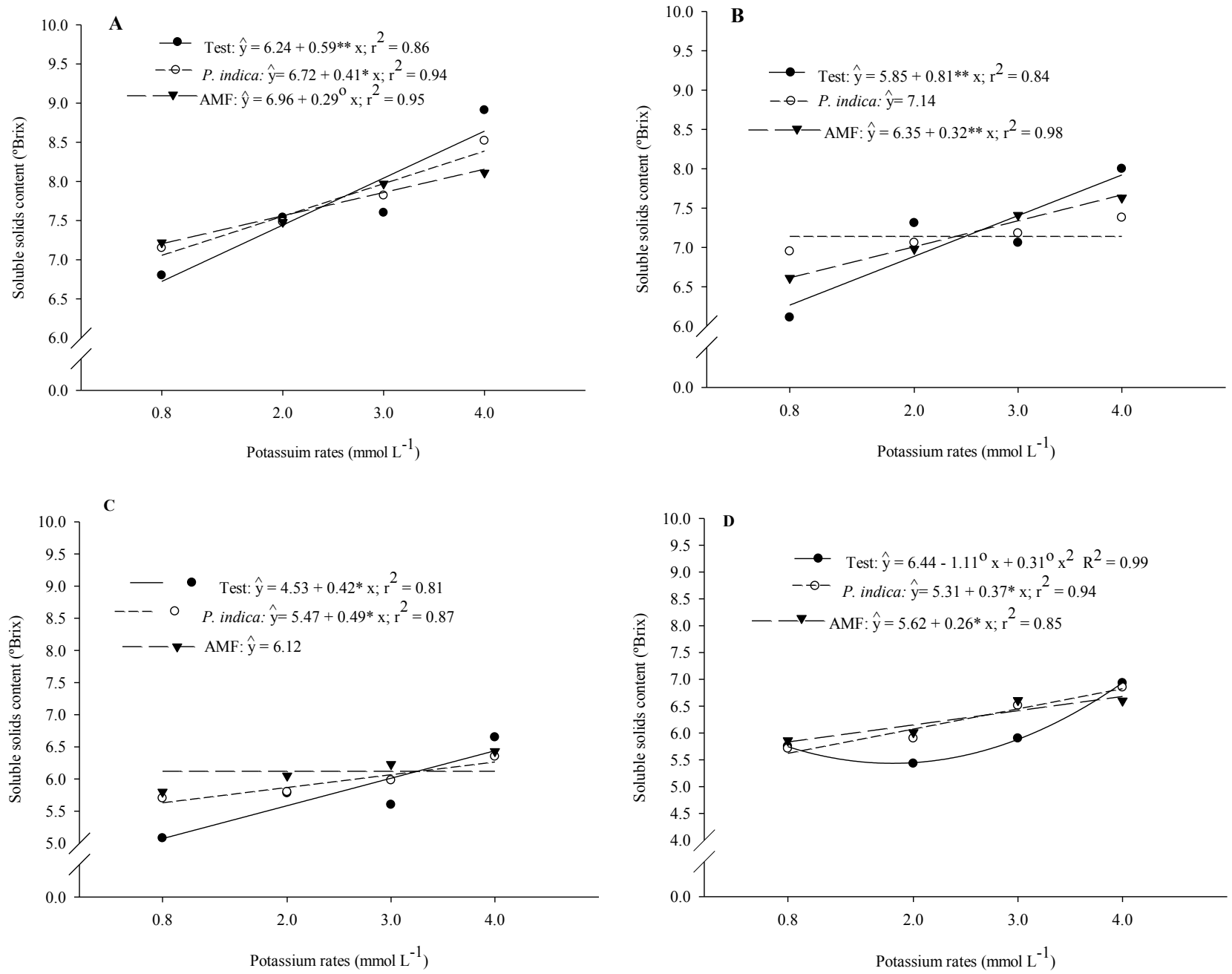

Figure 1. Soluble solids content ( ${ }^{\circ} \mathrm{Brix}$ ) of grape tomatoes stored at $25^{\circ} \mathrm{C}$ in response to potassium rates and inoculation with growth-promoting fungi, at $O(A), 10$ (B), 20 (C) and 30 (D) days of storage. ** Significant at $1 \%,{ }^{*}$ Significant at $5 \%$ and Significant at $10 \%$.

It is noteworthy that in tomato fruits, soluble solids consist of approximately $65 \%$ sugar, $13 \%$ acids and a residue of phenols, amino acids, soluble pectin, ascorbic acid and mineral nutrients. The SS content, expressed in ${ }^{\circ}$ Brix, is an indirect measure of the sugar content of fruits, and its values are positively related to consumer acceptance (Beckles, 2012).

The results shown in Table 1 and Figure 1 were somewhat expected, since at 0 DOS the processes of weight loss and biochemical changes stemming from storage had not yet begun, whereas at 30 DOS the positive effect of the association with GPF was no longer evident. Furthermore, storage provided a sharp decline in SS ('Brix) of the control fruits in the K-deficient concentration range $\left(0.8\right.$ to $\left.2 \mathrm{mmol} \mathrm{L}^{-1}\right)$. There are no reports of results in tomato that reinforce the results obtained in this study; however, they can probably be explained by the fact that the lack 
of $\mathrm{K}$ limits not only yield, but also potassium accumulation in the fruits. Such fruits with a lower $\mathrm{K}$ concentration showed a marked loss of quality with storage for 10 and 20 days, which was not observed in the fruits of inoculated plants (Figure 1). Additionally, during storage, fruit respiration leads to an increase in the consumption of reserves, resulting in a reduction in the amount of soluble solids.
Titratable acidity showed different responses to the interaction between GPF and $\mathrm{K}$ rates at 20 and 30 DOS (Table 2). At the time of harvest, there was no significant difference in the TA of the fruits of inoculated and uninoculated plants, but during storage, there was an upward trend in the TA of fruits of plants inoculated with $P$. indica, which became statistically significant at the high $\mathrm{K}$ rate $(4$ $\left.\mathrm{mmol} \mathrm{L}^{-1}\right)$ at $20 \mathrm{DOS}$ and at the low rate $(0.8$ $\mathrm{mmol} \mathrm{L}-1)$ at $30 \mathrm{DOS}$.

Table 2

Titratable acidity of grape tomatoes grown under $\mathrm{K}$ rates, inoculated with growth-promoting fungi and stored at $25^{\circ} \mathrm{C}$

\begin{tabular}{|c|c|c|c|c|c|c|c|c|}
\hline \multicolumn{9}{|c|}{ Storage time } \\
\hline \multirow{3}{*}{$\begin{array}{c}\text { Inoculation } \\
\text { treatment }\end{array}$} & \multicolumn{4}{|c|}{0 days } & \multicolumn{4}{|c|}{10 days } \\
\hline & \multicolumn{4}{|c|}{ Rate $\left(\mathrm{mmol} \mathrm{L}^{-1}\right)$} & \multicolumn{4}{|c|}{ Rate $\left(\mathrm{mmol} \mathrm{L}^{-1}\right)$} \\
\hline & 0.8 & 2 & 3 & 4 & 0.8 & 2 & 3 & 4 \\
\hline Control & $0.44 a$ & $0.50 a$ & $0.44 a$ & $0.45 a$ & $0.31 \mathrm{a}$ & $0.41 \mathrm{a}$ & $0.38 a$ & $0.46 a$ \\
\hline P. indica & $0.45 a$ & $0.45 a$ & $0.48 a$ & $0.50 \mathrm{a}$ & $0.34 \mathrm{a}$ & $0.31 \mathrm{a}$ & $0.38 a$ & $0.37 \mathrm{a}$ \\
\hline AMF & $0.43 a$ & $0.47 a$ & $0.40 a$ & $0.58 \mathrm{a}$ & $0.32 \mathrm{a}$ & $0.40 \mathrm{a}$ & $0.44 \mathrm{a}$ & $0.38 a$ \\
\hline \multicolumn{9}{|c|}{ Storage time } \\
\hline \multirow{3}{*}{$\begin{array}{l}\text { Inoculation } \\
\text { treatment }\end{array}$} & \multicolumn{4}{|c|}{20 days } & \multicolumn{4}{|c|}{30 days } \\
\hline & \multicolumn{4}{|c|}{ Rate $\left(\mathrm{mmol} \mathrm{L}^{-1}\right)$} & \multicolumn{4}{|c|}{ Rate $\left(\mathrm{mmol} \mathrm{L}^{-1}\right)$} \\
\hline & 0.8 & 2 & 3 & 4 & 0.8 & 2 & 3 & 4 \\
\hline Control & $0.35 a$ & $0.37 a$ & $0.35 a$ & $0.42 a b$ & $0.29 a$ & $0.30 a$ & $0.32 \mathrm{a}$ & $0.40 \mathrm{a}$ \\
\hline P. indica & $0.38 a$ & $0.37 a$ & $0.38 a$ & $0.49 a$ & $0.35 a$ & $0.42 a$ & $0.34 \mathrm{a}$ & $0.44 a$ \\
\hline AMF & $0.40 \mathrm{a}$ & $0.33 a$ & $0.44 a$ & $0.35 b$ & $0.33 b$ & $0.31 \mathrm{a}$ & $0.31 \mathrm{a}$ & $0.35 a$ \\
\hline CV (a) & \multicolumn{8}{|c|}{9.11} \\
\hline CV (b) & \multicolumn{8}{|c|}{13.02} \\
\hline $\mathrm{CV}$ (c) & \multicolumn{8}{|c|}{13.94} \\
\hline
\end{tabular}

Means followed by the same lowercase letter in the column do not differ from each other by Tukey's test at $5 \%$ probability. CV (a): coefficient of variation of the plot, CV (b): coefficient of variation of the subplot, CV (c): coefficient of variation of the sub-subplot.

These data reveal how inoculation in particular with $P$. indica was relevant for the preservation of fruits during the storage period, mainly in the fruits produced under nutritional stress conditions. In addition to contributing to the sensory properties of fruits, e.g., flavor, organic acids also play a critical role in maintaining their quality (Shui \& 
Leong, 2002). Other researchers also reported the benefits of the symbiotic association on fruit quality observed in this study. Copetta, Bardi, Bertoloni and Berta (2011) and Hart et al. (2014) also detected higher titratable acidity in tomato fruits produced by plants in association with GPF.

At harvest, in the fruits of uninoculated plants, the $K$ rates did not influence $T A$, which averaged $0.45 \%$. On the other hand, the TA of the fruits of inoculated plants showed a quadratic response to the $\mathrm{K}$ rates, increasing with the increase in $\mathrm{K}$ supply (Figure 2A). The TA of the tomato from plants inoculated with $P$. indica did not show a marked response to $K$ rates at 10 and 30 DOS (Figure 2B and 2D). Titratable acidity only responded quadratically at 20 DOS (Figure 2C). In the fruits of plants inoculated with $A M F$, there was a quadratic response at 10 and 30 DOS (Figure 2B and 2D).
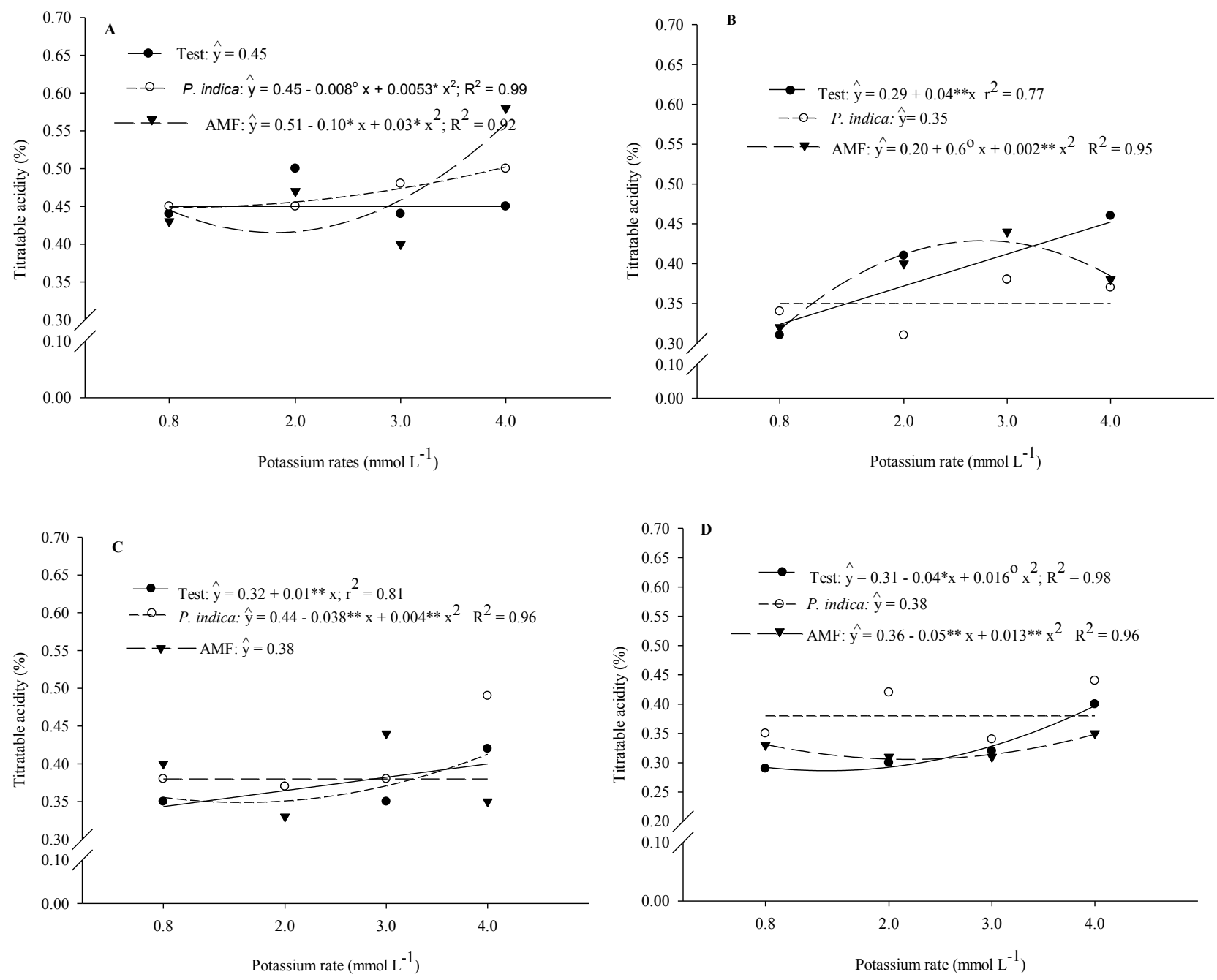

Figure 2. Titratable acidity (\%) of grape tomatoes stored at $25^{\circ} \mathrm{C}$ in response to potassium rates and inoculation with growth-promoting fungi, at 0 (A), 10 (B), 20 (C) and 30 (D) days of storage. ** Significant at $1 \%$, * Significant at $5 \%$ and Significant at $10 \%$. 
In fruits, acids typically decrease with storage time, as a result of their consumption for the ripening and senescence reactions. Thus, based on the behavior of the control fruits, it can be suggested that the $\mathrm{K}$ status in the inoculated plants (concentration in leaf tissues and fruit content) was much higher than in the uninoculated plants at harvest. All of these growth-promoting effects and nutritional physiology collectively resulted in noticeable improvements in the quality attributes of the grape tomato.

At 0 DOS, inoculation with $P$. indica favored the RS concentration only at the high $\mathrm{K}$ rate $\left(4 \mathrm{mmol} \mathrm{L}^{-1}\right)$. It is possible that the fungus helps to mitigate the effect of accumulation of $K$ salts in the sand. Salt accumulation is common in hydroponic drip systems and, in this case, the excess $\mathrm{K}$ may have resulted in impaired absorption of other cations and a saline effect. On that same occasion, the result obtained at the rate of $3 \mathrm{mmol} \mathrm{L} \mathrm{L}^{-1}$ could be due to a competition effect between the GPF and the plant for the produced photoassimilates. Therefore, in this case, the highest RS value occurred in the fruits of control plants (Table 3).

\section{Table 3}

Reducing sugars in grape tomatoes grown under $\mathrm{K}$ rates, inoculated with growth-promoting fungi and stored at $25^{\circ} \mathrm{C}$

\begin{tabular}{|c|c|c|c|c|c|c|c|c|}
\hline \multicolumn{9}{|c|}{ Storage time } \\
\hline \multirow{3}{*}{$\begin{array}{c}\text { Inoculation } \\
\text { treatment }\end{array}$} & \multicolumn{4}{|c|}{0 days } & \multicolumn{4}{|c|}{10 days } \\
\hline & \multicolumn{4}{|c|}{ Rate (mmol L-1) } & \multicolumn{4}{|c|}{ Rate $\left(\mathrm{mmol} \mathrm{L}^{-1}\right)$} \\
\hline & 0.8 & 2 & 3 & 4 & 0.8 & 2 & 3 & 4 \\
\hline Control & $3.92 \mathrm{a}$ & $3.59 a$ & $2.88 a$ & $4.82 \mathrm{a}$ & $2.64 \mathrm{~b}$ & $3.38 \mathrm{a}$ & $3.74 \mathrm{a}$ & $3.97 \mathrm{a}$ \\
\hline P. indica & $4.67 \mathrm{a}$ & $3.78 \mathrm{a}$ & $3.24 \mathrm{a}$ & $4.22 \mathrm{a}$ & $2.93 \mathrm{~b}$ & $3.77 \mathrm{a}$ & $3.49 a$ & $3.69 a$ \\
\hline AMF & $3.98 \mathrm{a}$ & $4.27 \mathrm{a}$ & $2.65 \mathrm{a}$ & $4.12 \mathrm{a}$ & $5.21 \mathrm{a}$ & $3.49 a$ & $3.96 \mathrm{a}$ & $4.43 a$ \\
\hline \multicolumn{9}{|c|}{ Storage time } \\
\hline \multirow{3}{*}{$\begin{array}{c}\text { Inoculation } \\
\text { treatment }\end{array}$} & \multicolumn{4}{|c|}{20 days } & \multicolumn{4}{|c|}{30 days } \\
\hline & \multicolumn{4}{|c|}{ Rate $\left(\mathrm{mmol} \mathrm{L}^{-1}\right)$} & \multicolumn{4}{|c|}{ Rate (mmol L-1) } \\
\hline & 0.8 & 2 & 3 & 4 & 0.8 & 2 & 3 & 4 \\
\hline Control & $2.43 b$ & $2.86 \mathrm{~b}$ & $3.60 \mathrm{a}$ & $6.90 \mathrm{~b}$ & $2.09 a$ & $3.36 \mathrm{a}$ & $2.73 \mathrm{a}$ & $3.55 a$ \\
\hline P. indica & $3.53 a$ & $2.58 b$ & $4.17 \mathrm{a}$ & $2.28 \mathrm{~b}$ & $2.49 a$ & $3.71 \mathrm{a}$ & $2.14 \mathrm{a}$ & $2.44 \mathrm{a}$ \\
\hline AMF & $3.24 a b$ & $3.66 \mathrm{a}$ & $3.54 \mathrm{a}$ & $6.9 a$ & $2.31 \mathrm{a}$ & $3.32 \mathrm{a}$ & $2.24 \mathrm{a}$ & $3.02 \mathrm{a}$ \\
\hline CV (a) & \multicolumn{8}{|c|}{28.52} \\
\hline$C V(b)$ & \multicolumn{8}{|c|}{39.37} \\
\hline CV (c) & \multicolumn{8}{|c|}{19.34} \\
\hline
\end{tabular}

Means followed by the same lowercase letter in the column do not differ from each other by Tukey's test at $5 \%$ probability. CV (a): coefficient of variation of the plot, CV (b): coefficient of variation of the subplot, CV (c): coefficient of variation of the sub-subplot. 
During storage, the fruits of plants inoculated with AMF had a higher RS content at the $\mathrm{K}$ rate of $0.8 \mathrm{mmol} \mathrm{L}^{-1}$ at $10 \mathrm{DOS}$ and at the rates of 2 and $4 \mathrm{mmol} \mathrm{L}^{-1}$ at 20 DOS (Table 3). Overall, these results suggest that the inoculation of plants subjected to nutritional stress (both lack and excess) favored the increase in RS content in the fruits during storage.

Inoculation can increase the plant's ability to synthesize photoassimilates, consequently improving fruit quality. However, Hart et al. (2014) investigated the impact of inoculation on the quality of tomato fruits and observed a reduction in fructose. These authors argued that colonization possibly represented a significant drain of carbon from the host plant.

The control fruits showed an increase in $\mathrm{RS}$ with the increasing $\mathrm{K}$ rates in all assessments. At 10, 20 and 30 DOS, the response was linear, and its magnitude increased with storage time (there was an increase in the angular coefficients of the straight lines). (Figure 3). The increasing RS of the fruits with the increasing rates of $\mathrm{K}$ shows that $\mathrm{K}$ can play an important role in shaping the quality profile of tomato fruits. Potassium is the most abundant cation present in the phloem sap of tomato (almost $80 \%$ of the total cations), as a consequence of sugar loading and transport mechanisms through the phloem to draining organs (Cakmak, 2005). Potassium is known to play a key role in carbohydrate metabolism and photosynthesis (Marschner, 2012) and, as a consequence, an optimal supply of potassium determines a higher sugar content in the draining organs.

Overall, the results indicate a greater stability of the reducing sugar contents in the fruits obtained from inoculated plants (Figure 3), showing a stabilizing effect of the association between tomato and GPF. This effect is especially desirable under a low supply of $\mathrm{K}$ from the external environment. 

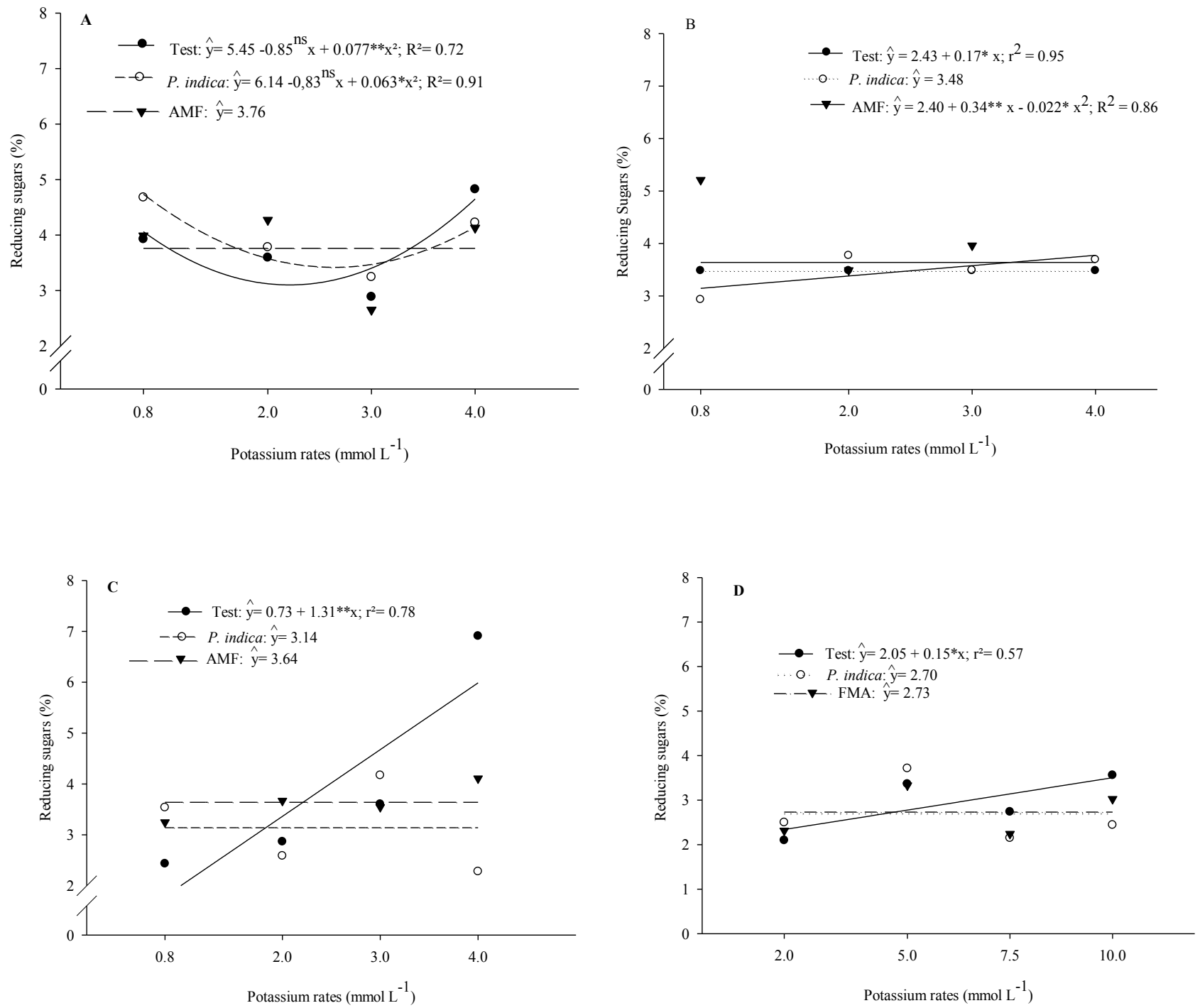

Figure 3. Reducing sugars (\%) of grape tomatoes stored at $25^{\circ} \mathrm{C}$ in response to potassium rates and inoculation with growth-promoting fungi, at 0 (A), 10 (B), 20 (C) and 30 (D) days of storage. ** Significant at $1 \%,{ }^{*}$ Significant at $5 \%$ and Significant at $10 \%$.

At harvest, the vit. $\mathrm{C}$ content was higher in the fruits of inoculated plants at the $\mathrm{K}$ rates of 2 and $3 \mathrm{mmol} \mathrm{L}^{-1}$. During storage, there was a significant effect of inoculation on the vit. $\mathrm{C}$ content of the fruits of plants inoculated with $P$ indica that were cultivated with $3 \mathrm{mmol} \mathrm{L}^{-1} \mathrm{~K}$ at $10 \mathrm{DOS}$ and with $0.8 \mathrm{mmol} \mathrm{L}^{-1} \mathrm{~K}$ at 30 DOS (Table 4). The increased vit. C concentration in the fruits of inoculated plants at the rates representing better $\mathrm{K}$ nutrition may be related to the greater availability of sugars, which are substrates for vit. C biosynthesis (Cruz-Rus, Amaya, Sanchez-Sevilla, Botella, \& Valpuesta, 2011), and to the different symbiosis-induced citric acid cycle regulation.

At harvest, the control fruits showed a quadratic response in vit. C content to potassium, with lower values occurring 


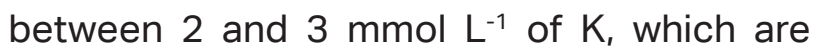
probably related to lower nutrition with $\mathrm{K}$ at these rates. At $10 \mathrm{DOS}$, the vit. $\mathrm{C}$ content decreased with the $K$ rates, then remained stable at 20 DOS and finally increased at 30 DOS (Figure 4).

The vit. C content of the fruits obtained from inoculation with $P$. indica did not respond to the $\mathrm{K}$ rates in the first three evaluations, averaging $46.99 \mathrm{mg} / 100 \mathrm{~mL}$ at harvest, 41.27 $\mathrm{mg} / 100 \mathrm{~mL}$ at $10 \mathrm{DOS}$ and $54.65 \mathrm{mg} / 100 \mathrm{~mL}$ at 20 DOS. At 30 DOS, the response followed a decreasing quadratic pattern, with a minimum point around $3 \mathrm{mmol} \mathrm{L}^{-1}$ of $\mathrm{K}$.
At harvest, fruits obtained from inoculation with AMF showed an increasing quadratic variation in their vit. $C$ contents, with maximum values achieved at $\mathrm{K}$ levels close to $2 \mathrm{mmol} \mathrm{L}^{-1}$. At 10 and 30 DOS, the vit. $C$ values did not respond to the $\mathrm{K}$ rates in these plants, averaging 39.59 and $56.12 \mathrm{mg} / 100 \mathrm{~mL}$, respectively. At 20 DOS, fruits obtained from inoculation with AMF responded quadratically to the $\mathrm{K}$ rates, with lower values attained near the rate of $3 \mathrm{mmol} \mathrm{L}^{-1}$ (Figure 4).

\section{Table 4}

Vitamin $\mathrm{C}$ in grape tomatoes grown under $\mathrm{K}$ rates, inoculated with growth-promoting fungi and stored at $25^{\circ} \mathrm{C}$

\begin{tabular}{|c|c|c|c|c|c|c|c|c|}
\hline \multicolumn{9}{|c|}{ Storage time } \\
\hline \multirow{3}{*}{$\begin{array}{l}\text { Inoculation } \\
\text { treatment }\end{array}$} & \multicolumn{4}{|c|}{0 days } & \multicolumn{4}{|c|}{10 days } \\
\hline & \multicolumn{4}{|c|}{ Rate $\left(\mathrm{mmol} \mathrm{L}^{-1}\right)$} & \multicolumn{4}{|c|}{ Rate $\left(\mathrm{mmol} \mathrm{L}^{-1}\right)$} \\
\hline & 0.8 & 2 & 3 & 4 & 0.8 & 2 & 3 & 4 \\
\hline Control & $51.46 a$ & $35.57 \mathrm{~b}$ & $36.61 \mathrm{~b}$ & $46.57 \mathrm{a}$ & $56.69 a$ & $43.43 a$ & $35.76 b$ & $34.51 a$ \\
\hline P. indica & $47.02 \mathrm{a}$ & $55.69 a$ & $38.96 \mathrm{ab}$ & $46.30 \mathrm{a}$ & $38.46 a$ & $35.58 a$ & $50.98 a$ & $40.09 a$ \\
\hline AMF & $50.37 a$ & $57.91 \mathrm{a}$ & 49.72 a & $43.22 \mathrm{a}$ & $36.58 a$ & $47.67 a$ & $32.87 b$ & $41.21 a$ \\
\hline \multicolumn{9}{|c|}{ Storage time } \\
\hline \multirow{3}{*}{$\begin{array}{c}\text { Inoculation } \\
\text { treatment }\end{array}$} & \multicolumn{4}{|c|}{20 days } & \multicolumn{4}{|c|}{30 days } \\
\hline & \multicolumn{4}{|c|}{ Rate $\left(\mathrm{mmol} \mathrm{L}^{-1}\right)$} & \multicolumn{4}{|c|}{ Rate $\left(\mathrm{mmol} \mathrm{L}^{-1}\right)$} \\
\hline & 0.8 & 2 & 3 & 4 & 0.8 & 2 & 3 & 4 \\
\hline Control & $61.95 a$ & $49.15 \mathrm{a}$ & $72.62 \mathrm{a}$ & $53.46 a$ & $44.83 \mathrm{~b}$ & $48.56 \mathrm{a}$ & $45.37 a$ & $65.95 a$ \\
\hline P. indica & $55.86 a$ & $42.62 \mathrm{a}$ & $71.45 a$ & $60.64 a$ & $61.58 a$ & $50.53 a$ & $48.96 \mathrm{a}$ & $54.36 \mathrm{a}$ \\
\hline AMF & $53.89 a$ & $41.68 \mathrm{a}$ & $46.91 b$ & $62.13 \mathrm{a}$ & $48.24 a$ & $65.85 a$ & $48.54 \mathrm{a}$ & $65.95 \mathrm{a}$ \\
\hline CV (a) & \multicolumn{8}{|c|}{8.99} \\
\hline CV (b) & \multicolumn{8}{|c|}{25.11} \\
\hline $\mathrm{CV}$ (c) & \multicolumn{8}{|c|}{10.98} \\
\hline
\end{tabular}

Means followed by the same lowercase letter in the column do not differ from each other by Tukey's test at $5 \%$ probability. CV (a): coefficient of variation of the plot, CV (b): coefficient of variation of the subplot, CV (c): coefficient of variation of the sub-subplot. 

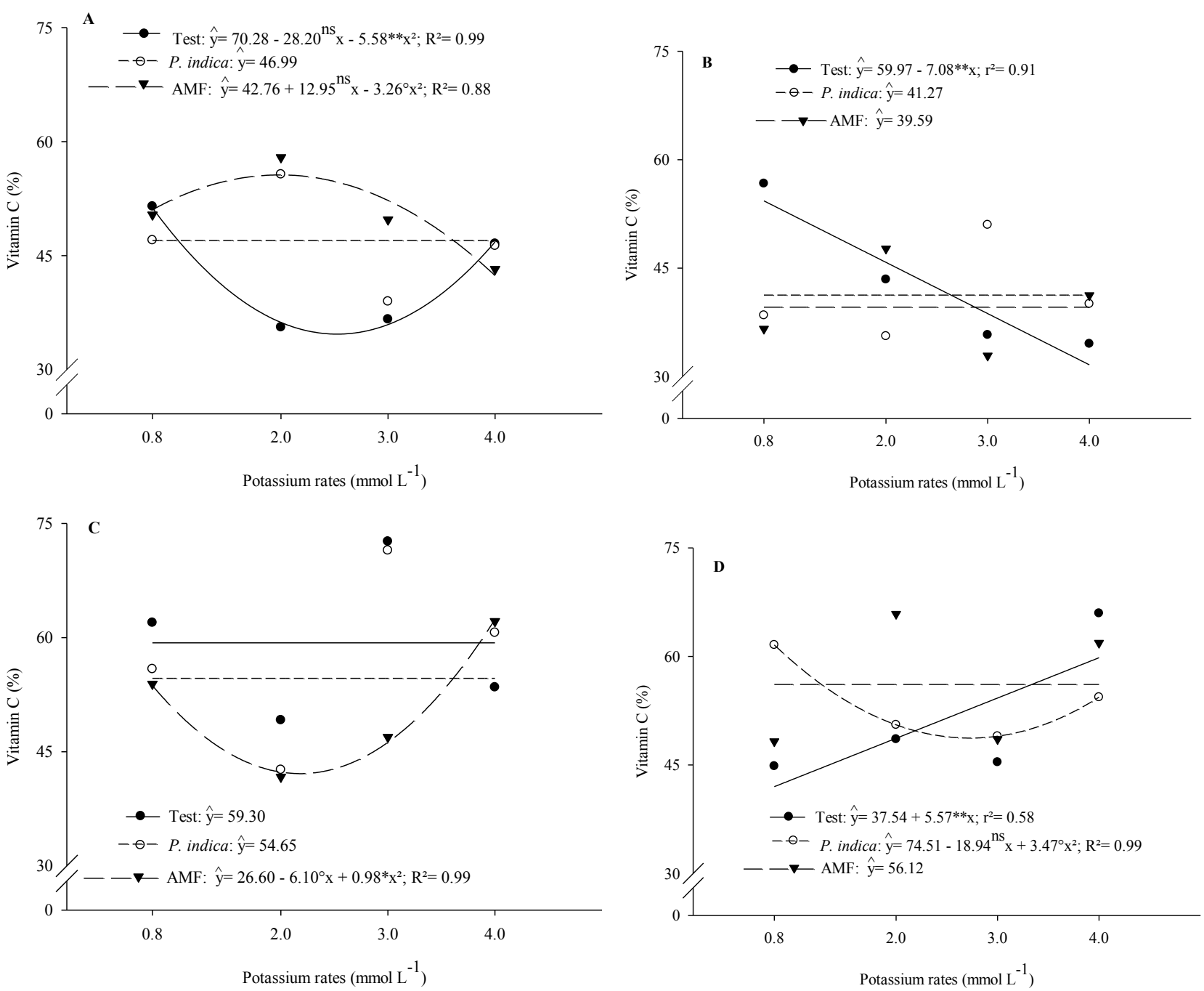

Figure 4. Vitamin $\mathrm{C}(\%)$ in grape tomatoes stored at $25{ }^{\circ} \mathrm{C}$ in response to potassium rates and inoculation with growth-promoting fungi, at 0 (A), 10 (B), 20 (C) and 30 (D) days of storage.

** Significant at $1 \%,{ }^{*}$ Significant at $5 \%$ and Significant at $10 \%$.

As mentioned above, the vit. $\mathrm{C}$ content can be influenced by several factors before and after harvest. Potassium fertilization is one of the factors that influence its content in fruits (Kanai, Ohkura, Adu-Gyamfi, \& Mohopatra, 2007), as it can improve the activity of ascorbate peroxidase (APX) in tomato resulting in better vit. $\mathrm{C}$ contents under a certain $\mathrm{K}$ rate. Furthermore, higher temperatures or longer storage leads to a gradual decrease in the vit. $\mathrm{C}$ content of fruits (Mditshwa, Magwaza, Tesfay, \& Opara, 2017). In the present study, overall, the $\mathrm{K}$ rates had little influence on the vit. $\mathrm{C}$ content at the studied storage periods. Fruits from inoculated plants showed greater stability in their vit. $\mathrm{C}$ content during storage, regardless of the $\mathrm{K}$ rate (Table 4, Figure 4). 


\section{Conclusions}

The inoculation of grape tomato 'Mascot' plants with growth-promoting fungi improves and provides an improvement and stability of fruit quality during storage, especially in fruits from plants grown under low or high $\mathrm{K}$ rates.

Fruits from plants grown under higher $\mathrm{K}$ rates have better quality at harvest and during storage.

\section{Acknowledgments}

To Coordenação de Aperfeiçoamento de Pessoal de Nível Superior - Brasil (CAPES) - Finance Code 001, Fundação de Amparo à Pesquisa do Estado de Minas Gerais (FAPEMIG) and Conselho Nacional de Desenvolvimento Científico e Tecnológico (CNPq) for the financial support and fellowship grants.

\section{References}

Achatz, B., Rüden, S., Andrade, D., Neumann, E., Pons-Kühnemann, J., Kogel, K. H., \& Waller, F. (2010). Root colonization by Piriformosporaindica enhances grainyield in barley under diverse nutrient regimes by acceleratingplant development. Plant and Soil, 333(1), 59-70. doi: 10.1007/s11 104-010-0319-0

Alvarenga, M. A. R. (2013). Tomate: produção em campo, em casa de vegetação e em hidroponia (2a ed.). Lavras MG: Universitária de Lavras.

Asaduzzaman, M. D., \& Asao, T. (2018). Potassium - improvement of quality in fruits and vegetables through hydroponic nutrient management. London, UK: IntechOpen.

Beckles, D. M. (2012). Factors affecting the postharvest soluble solids and sugar content of tomato (Solanum lycopersicum L.) fruit. Postharvest Biology and Technology, 63(1), 129-140. doi: 10.1016/j.postharvbio.2011.05.016

Bettiol, W., Astiarraga, B. D., \& Luiz, A. J. B. (1999). Effectiveness of cow's milk against zucchini squash powdery mildew (Sphaerotheca fuliginea) in greenhouse conditions. Crop Protection, 18(8), 489-492, doi: 10.1016/S0261-21 94(99)00046-0

Boldt, K., Pörs, Y., Haupt, B., Bitterlich, M., Kühn, C., Grimm B., \& Franken, P. (2011). Photochemical processes, carbon assimilation and RNA accumulation of sucrose transporter genes in tomato arbuscular mycorrhiza. Journal of Plant Physiology, 168(11), 256-1263. doi: 10. 1016/j.jplph.2011.01.026

Cakmak, I. (2005). The role of potassium in alleviating detrimental effects of abiotic stresses in plants. Journal of Plant Nutrition and Soil Science, 168(4), 521530. doi: 10.1002/jpln.200420485

Chitarra, M. I. F., \& Chitarra, A. B. (2005). Póscolheita de frutos e hortaliças: fisiologia e manuseio (2a ed.). Lavras, MG: Editora UFLA.

Copetta, A., Bardi, L., Bertolone, E., \& Berta, G. (2011). Fruit production and quality of tomato plants (Solanum lycopersicum L.) are affected by green compost and arbuscular mycorrhizal fungi. Plant Biosystems, 145(1), 106-115. doi: 10.10 80/11263504.2010.539781 
Cruz-Rus, E., Amaya, I., Sanchez-Sevilla, J. F., Botella, M. A., \& Valpuesta, V. (2011). Regulation of L-ascorbic acid content in strawberry fruits. Journal of Experimental Botany, 62(12), 4191-4201. doi: 10.1093/ jxb/err122

Eloi, W. M., Duarte, S. N., \& Soares, T. M. (2007). Níveis de salinidade e manejo da fertirrigação sobre características do tomateiro cultivado em ambiente protegido. Revista Brasileira de Ciências Agrárias, 2(1), 83-89. doi: 10.1590/S180666902013000100019

Emmanuel, O. C., \& Babalola, O. O. (2020). Productivity and quality of horticultural crops through co-inoculation of arbuscular mycorrhizal fungi and plant growth promoting bacteria. Microbiological Research, 239(1), 1-11 doi: 10.1016/j.micres.2020.126569

Fernandes, A. A., Martinez, H. E. P., \& Fontes, P. C. R. (2002). Produtividade, qualidade dos frutos e estado nutricional do tomateiro tipo longa vida conduzido com um cacho, em cultivo hidropônico, em função das fontes de nutrientes. Horticultura Brasileira, 20(4), 564-570. doi: 10.1590/ S0102-05362002000400011

Ferraz, E. O., Evangelista, R. M., Cláudio, M. T. R., Soares, L. P. R., Silva, B. L., \& Cardoso, A. I. I. (2012). Características físicoquímicas em tomates cereja tipo Sweet Grape envolvidos por diferentes películas protetoras. Horticultura Brasileira, 30(2), 7115-7122.

Giovannetti, M., Avio, L., Barale, R., Ceccarelli, N., Cristofani, R., lezzi, A., Scarpato, R. (2012). Nutraceutical value and safety of tomato fruits produced by mycorrhizal plants.
British Journal of Nutrition, 107(2), 242251. doi: 10.1017/S000711451100290X

Gonçalves, C., Rodrigues-Jasso, M. R., Gomes, N., Teixeira, J. A., \& Belo, I. (2010). Adaptation of dinitrosalicylic acid method to microtiter plates. Analytical Methods, 2(12), 2046-2048. doi: 10.1039/c0ay0 $0525 h$

Hart, M., Ehret, D. L., Krumbein, A., Leung, C., Murch, S., Turi, C., \& Franken, P. (2014). Inoculation with arbuscular mycorrhizal fungi improves the nutritional value of tomatoes. Mycorrhiza, 25(5), 359-376. doi: 10.1007/s00572-014-0617-0

Kanai, S., Ohkura, K., Adu-Gyamfi, J., \& Mohopatra, P. (2007). Depression of sink activity precedes the inhibition of biomass production in tomato plants subjected to potassium deficiency stress. Journal of Experimental Botany, 58(11), 2917-2928. doi: 10.1093/brain/awl024

Kawakami, F. P. C., Araujo, J. A. C., lunck, A. V., Factor, T.L.\& Cortez, G.E. (2007). Manejo da fertirrigação em função da condutividade elétrica da solução nutritiva drenada no cultivo de tomate cereja sob ambiente protegido. Anais do Congresso Brasileiro de Olericultura, Vitória da Conquista, BA, Brasil, 47.

Liu, K., Zhang, T. Q., Tan, C. S., \& Astatkie, T. (2011). Responses of fruit yield and quality of processing tomato to drip-irrigation and fertiizers phosphorus and potassium. Agronomy Journal, 103(5), 330-1345. doi: 10.2134/agronj2011.0111

Marschner, P. (2012). (Ed). Mineral nutrition of higher plants (3nd ed.). London, UK: Elsevier. 
McCready, R. M., Guggolz, J., Silveira, V., \& Owens, H. S. (1950). Determination of starch and amylase in vegetables. Analytic Chemistry, 22(9), 1156-1158. doi: 10.1021/ac60045a016

Mditshwa, A., Magwaza, L., Tefay, S. Z., \& Opara, U. L. (2017). Postharvest factors affecting vitamin $\mathrm{C}$ content of citrus fruits: a review. Scientia Horticulturae, 218(1), 95-104. doi: 10.1016/j.scienta.2017.02. 024

Shui, G., \& Leong, L. (2002). Separation and determination of organic acids and phenolic compounds in fruit juice and drinks by high performance liquid chromatography. Journal of Chromatography A 977(1), 89-96. doi: 10.1016/S0021-9673(02)01345-6

Sonntag, F., Naumann, M., Pawelzik, E., \& Smit, I. (2019). Improvement of cocktail tomato yield and consumer-oriented quality traits by potassium fertilization is driven by the cultivar. Journal of the Science of Food and Agriculture, 99(7), 3350-3358. doi: 10.1002/jsfa.9552

Strohecker, R., \& Henning, H. M. (1967). Análisis de vitaminas. Madrid ES: Paz Montalvo.
Taiz, L., Zeiger, E., Moller, I. M., \& Murphy, A. (2017). Fisiologia e desenvolvimento vegetal (6a ed.). Porto Alegre, RS: Artmed.

Varma, A., Bakshi, M., Lou, B., Hartmann, A., \& Oelmueller, R. (2012). Piriformospora indica: a novel plant growth-promoting mycorrhizal fungus. Agricultural Research, 1(2), 117-131. doi: 10.1007/s40003-0120019-5

Wang, H., Zheng, J., Ren, X., Yu, T., Varma, A., Lou, B., \& Zheng, X. (2015). Effects of Piriformospora indica on the growth, fruit quality and interaction with Tomato yellow leaf curl virus in tomato cultivars susceptible and resistant to TYCLV. Plant Growth Regulation, 76(3), 303-313. doi: 10.1007/s10725-015-0025-2

Yadav, K., Aggarwal, A., \& Singh, N. (2013). Arbuscular mycorrhizal fungi (AMF) induced acclimatization, growth enhancement and colchicine content of micropropagated Gloriosa superba L. plantlets. Industrial Crops and Products, 45(1), 88-93. doi: 10.1016/j. indcrop.2012.12.00 
